\title{
The National Disability Insurance Scheme in an urban context: opportunities and challenges for Australian cities
}

\begin{abstract}
The NDIS will directly affect the lives of close to half a million people with a disability as well as their formal and informal support providers. In doing so, the $\$ 22$ billion per annum scheme will have significantly wider impacts on Australian cities. This review paper examines the urban policy and practice context for the NDIS and provides a research agenda for examining the challenges and opportunities the scheme brings. We examine a set of urban policy domains, including housing, employment, governance, mainstream services (particularly health and education) and multiculturalism. We argue that the current Australian urban condition is hardly ideal for the implementation of such an ambitious scheme. Yet, the NDIS will enhance the support available for greater participation of people with disabilities in their communities, and with appropriate adjustments to mainstream urban policy the scheme can make important positive contributions to the social, cultural and economic thriving of Australian cities.
\end{abstract}

Keywords: Disability; National Disability Insurance Scheme; Housing; Employment; Health; Diversity

\section{Introduction}

Considered one of the most significant social policy reforms in Australian history, "epochal" (Goggin and Wadiwel, 2014) in its scale and transformative potential, the NDIS will directly affect the lives of close to half a million people with a disability as well as their formal and informal support providers. As one of the most urbanised countries in the world, these impacts will be profoundly influenced by the urban contexts in which the NDIS will operate. In turn, Australian cities themselves are likely to face new opportunities and challenges as they adapt to the significant social, economic and political transformations facilitated by the NDIS.

This paper reviews the urban policy and practice context for the NDIS and sets out a research agenda for examining the impacts of the NDIS on Australia's major cities, where almost $80 \%$ of the population lives (Major Cities Unit, 2015, p. 14). Thus, our review considers how the NDIS will be practised as a largely urban phenomenon and what issues this is likely to raise

Pre-publication 'accepted' version

For full publication visit: https://www-tandfonlinecom.ezp.lib.unimelb.edu.au/doi/abs/10.1080/08111146.2018.1481026 
for urban scholarship and practice. We speculate that the NDIS is likely to create new urban geographies, especially in our complex, fast evolving metropolitan regions, which bear serious scholarly consideration. Our examination considers the broad domains in which the scheme is likely to facilitate urban change in Australia, including housing, employment, governance, mainstream services and multiculturalism. In relation to each of these domains, the paper will consider potential implications, opportunities and challenges associated with the NDIS.

The NDIS will face a different set of challenges in non-urban areas. The Productivity Commission (2011), has raised concerns about the quality and availability of both specialist and mainstream services for people with disability in non-urban areas, due to issues such as remoteness and smaller size of 'markets' (i.e. the number of NDIS participants) which "present considerable challenges for service provider viability, effective competition, consumer choice, infrastructure adequacy and availability of specialists" (Productivity Commission, 2011, p. 528). On the other hand, lower land values in most non-urban areas present opportunities, especially in terms of Specialist Disability Accommodation and mainstream affordable housing provision. Due to the distinctive challenges and impacts of the NDIS on non-urban areas, the remit of this paper is more narrowly focused on urban Australia.

Before addressing these questions, we first outline some of the defining features of the NDIS, and revisit earlier Australian and international studies on deinstitutionalisation. This great service reform provides a relatively recent and substantial comparator of a paradigm shift in the disability sector that was researched within its urban contexts.

\section{What is the NDIS?}

The NDIS was initiated in 2013 to transform an "inequitable, underfunded, fragmented, and inefficient" (Productivity Commission, 2011, p. 5) support services system for people with disability in Australia. Promoting independent living and community participation are two of the scheme's primary objectives (Productivity Commission, 2011). Annual funding for disability services will increase from a total of \$7 billion in 2012-13 (prior to the scheme's launch) to $\$ 22$ billion in 2019-20, when the scheme is fully operational nationally. Currently, the majority of disability services are block funded, with fixed amounts provided to service

Pre-publication 'accepted' version

For full publication visit: https://www-tandfonlinecom.ezp.lib.unimelb.edu.au/doi/abs/10.1080/08111146.2018.1481026 
providers. In contrast, most NDIS funding will be allocated to people with disability as individualised funding. This fundamental shift was designed to facilitate greater choice and control for people with disability, enabling them to purchase their preferred support services in a quasi-market system (as opposed to administrative allocation of services). Approximately a fifth of the Australian population (four million people) have a disability. Of these, only 460,000 people are expected to be eligible for individualised NDIS funding (NDIS, 2018). This group (often referred to as NDIS participants) includes people with a significant and ongoing disability, under 65 years old at the time of entering the scheme. The majority, an estimated 70\%, of NDIS participants will be people with intellectual disability (Bonyhady, 2016). In addition, the NDIS Information, Linkages and Capacity Building (ILC) program will provide grant funding for projects that assist in building personal and community capacity that enhance community inclusion for all Australians with disability (NDIS, n.d.).

\section{Deinstitutionalisation as a precursor}

Deinstitutionalisation was the last major paradigm shift in Western disability services. It was shaped to a large extent by the urban contexts in which it took place, and has left its own lasting mark on cities around the world. Deinstitutionalisation involved the closure of large state run institutions, which had housed people with primarily intellectual or psychosocial disabilities. Deinstitutionalisation was initiated in North America and Scandinavia in the 1970s following a series of grassroots campaigns, government reports and inquiries as well as academic studies which exposed the inhumane living conditions in institutions. It was deeply connected to the broader civil rights movements of that era (Wiesel and Bigby, 2015). In Australia, deinstitutionalisation started later, in the 1980s, and was closely connected to wider urban changes and policy programs. Throughout the 1990s, the Commonwealth Better Cities Program (BCP) provided seed funding for institution closures in several Australian cities, as a means to release land for alternative uses better aligned with the BCP's urban development agenda (NCA 1996, p. 91).

Deinstitutionalisation saw the establishment of thousands of group homes and community care facilities throughout Australian suburbia. Many of these developments triggered localised community resistance in the form of NIMBY (not in my backyard) activism and

Pre-publication 'accepted' version

For full publication visit: https://www-tandfonlinecom.ezp.lib.unimelb.edu.au/doi/abs/10.1080/08111146.2018.1481026 
protest (Gleeson, 1999). This echoed earlier discriminatory localised resistance to community care in North America (Whitzman and Slater, 2006).

Deinstitutionalisation is considered one of several factors in the changing demographics of social housing in Australia, and its reinvention as a housing tenure for the most disadvantaged urban populations. When established in Australia after the Second World War, public housing served as housing for returning soldiers and lower-paid workers in manufacturing jobs (Hayward, 1996; Jones, 1972). Deinstitutionalisation-alongside other demographic and social changes, such as population ageing, and growth in single parenthood-increased demand for public housing among more disadvantaged groups. From 1982 to 2002, the number of public renters with a Disability Support Pension (DSP) has more than tripled. This was driven by growth in the total number of DSP recipients, which was more pronounced among public renters compared to other tenures (Dalton and Ong, 2007). At the same time, the decline in provision of new social housing as well as the virtual eradication of privately run rooming and boarding houses has added to homelessness amongst people with disability (Chamberlain and Mackenzie, 2014). While the notion that institutional residents were discharged into homelessness is a common misconception (MHCA, 2009, p. 22), the rising incidence of homelessness and imprisonment among people with mental health problems and mild cognitive disabilities is closely associated with insufficient provision of community care services, including affordable and supportive housing (Baldry et al., 2012).

\section{The NDIS in an urban context}

The Australian deinstitutionalisation experience provides important lessons about the potential impacts of the NDIS on Australian cities. However, three important caveats need to be acknowledged.

First, the scale and scope of the NDIS is considerably larger than that of the Australian deinstitutionalisation movement. Since 1988, deinstitutionalisation in Australia has involved the rehousing of fewer than 7000 people with intellectual disability who lived in institutions. ${ }^{1}$ Psychiatric institution beds declined from 30,000 in 1961 to less than 7000 in 2014 (Whiteford and Buckingham, 2005; MSHA, n.d.). By contrast, the NDIS, as discussed above, will directly affect the lives of nearly half a million Australians with a disability.

Second, deinstitutionalisation was planned and managed by Australian state governments, whereas the NDIS will be managed at the national level. It is premised on the philosophies of

Pre-publication 'accepted' version

For full publication visit: https://www-tandfonlinecom.ezp.lib.unimelb.edu.au/doi/abs/10.1080/08111146.2018.1481026 
individualised and marketised welfare (Bonyhady, 2016), and unlike similar developments in the UK, will rely on consumer demand rather than local or state government commissioning service development. As Searle and Bunker (2010) point out, Australian state governments are responsible for most service and infrastructure planning, including a growing interest in social housing as infrastructure. Unlike the UK and the US, the federal government does not tend to engage in what it sees as 'urban' issues, including spatial planning concerns. This may lead to problems with vertical service policy integration between the national, state and local scales of government.

Third, Australian cities have changed dramatically since the beginnings of deinstitutionalisation (Gleeson, 2017). They are now more populated, with Melbourne and Sydney's population nearly doubling since 1981 (ABS, 2016). Overseas migration, the primary driver of population growth, has influenced the cultural diversity of Australian cities (AHRC, n.d.), and brought significant pressure on existing urban infrastructures and services (Troy, 2017).

Since the 1980s, Australian cities have undergone fundamental economic restructuring, following a "landmark period of massive reform and deregulation" (Stimson, 2012, p. 23). Manufacturing jobs have declined in the face of a rising new economy of telecommunications, research and development, finance, design and marketing with the benefits of economic growth spread unevenly resulting in stark variations in the geographic patterns of opportunity and vulnerability (Stimson, 2012, p. 26). This has lead to increased socio-spatial polarisation, including a rising income gap between the wealthiest and the poorest (Whiteford, 2013, p. 70) and the rise of a so-called 'precariat class' experiencing sustained underemployment, including rising part-time employment and employment insecurity, affecting primarily those with lower incomes (OECD, 2016). In spatial terms, the suburbanisation of disadvantage saw the lowest income populations shifting further away from an increasingly gentrified metropolitan core (Baum and Gleeson, 2010; Randolph and Tice, 2016).

Socioeconomic polarisation has been worsened by the rising costs of housing in Australian cities-primarily Melbourne and Sydney-well above wage growth, with negative impact on first time home buyers and private renters (Yates, 2011, pp. 6-7; Stone, 2015). A recent survey by Anglicare (2015) found that only 1\% of 65,000 surveyed rental properties would be affordable and suitable for a single income-support recipient; and only $2.3 \%$ would be

Pre-publication 'accepted' version For full publication visit: https://www-tandfonlinecom.ezp.lib.unimelb.edu.au/doi/abs/10.1080/08111146.2018.1481026 
affordable for a single person on minimum wage. The supply of social housing has failed to keep pace with rising levels of demand, with the proportion of social renters in the population falling from 5.8\% of households in 1998 to $3.9 \%$ in 2010 (NHSC, 2013).

It is in this broad urban landscape that the NDIS is being implemented in Australia. The NDIS is a person centred scheme, taking a holistic approach to the support it provides for people with disability across their varied life domains. In the following sections we focus on five urban domains with which the NDIS is likely to interact: housing, employment, mainstream services, governance and multiculturalism.

\section{Housing}

The availability of individualised NDIS funding means participants will no longer be tied to a specific service or home in order to receive the level of support they require. Many will be able to access the day-to-day support they need to live more independently in the community. A small proportion (6\%) of all NDIS participants will be able to access specialist housing funded by the Scheme. However, the shortage in affordable housing proximate to suitable employment and health and social services in Australia's major cities is likely to constrain independent living and community participation options for most other NDIS participants (Wiesel et al., 2015). As a comment in Infrastructure Victoria's recent 30-year strategy (2016, p. 103) suggested : "Introduction of this scheme [NDIS] is likely to impact on the demand for social housing, but exactly how it will do so is unknown".

The NDIS will fund Specialist Disability Accommodation (SDA) for participants who have an extreme functional impairment or very high support needs. Approximately 27,000 NDIS participants - representing about $6 \%$ of all the Scheme's participants, those with the highest level of support needs - will be eligible for SDA, including an approximately 15,000 people who already live in shared supported accommodation (group homes).

SDA will bring a number of very welcome changes to the Australian supported accommodation system for those who are eligible. The increase in SDA stock will reduce waitlists and increase specialist housing options to choose from. Furthermore, rather than the 'one-size-fits-all' group home model of recent decades, where new stock was largely planned and controlled by the State, under the NDIS there will be a more market-led approach to the development of new stock and a wider range of 'SDA types', ranging from apartments for a single resident, through to group homes and intentional communities. New housing choices

Pre-publication 'accepted' version

For full publication visit: https://www-tandfonlinecom.ezp.lib.unimelb.edu.au/doi/abs/10.1080/08111146.2018.1481026 
that have not existed before include SDA residents living with a partner or children who are not eligible for SDA payments, registered as their own housing provider (creating pathways into homeownership), or making discretionary rent contributions to access a higher cost SDA type or location. These new options significantly increase choice and control in housing, but in practice only for those who are better resourced either financially or in terms of their capacities and support networks (for example to manage enrolment and compliance as a registered SDA provider for one-self). There are also concerns about the relatively weak restrictions the NDIS has specified in relation to funding new or existing congregate housing developments (Wiesel et al., 2017) which the evidence demonstrates do not have the potential to lead to the type of inclusive outcomes for residents the NDIS aims to achieve (Mansell and Beadle- Brown, 2009)

Notwithstanding the importance of SDA, the vast majority of NDIS participants (94\%) will not be eligible for any NDIS assistance with housing costs. According to the Disability Housing Futures Working Group (DHF, 2016), of 460,000 prospective National Disability Insurance Scheme (NDIS) participants, approximately 110,000 are currently inadequately housed. This includes adults living with parents $(50,000)$, in congregate accommodation $(20,000)$, in unaffordable private rental $(35,000)$ or experiencing homelessness $(5,000)$. A major concern is the negative implications of inadequate housing on people with disabilities' health, independence, access to informal support networks, mainstream services and employment opportunities (Disability Housing Futures, 2017; Wiesel et al., 2015). At the same time, an expected increase in the concentration of people with disability in social housing - over and above the $40 \%$ of households that currently include a person with a disability (AIHW, 2017) - could potentially constrain social housing access for other urban populations in need, such as the elderly, refugees and single mothers.

\section{Workforce}

One of the main goals of the NDIS, as envisaged by the Productivity Commission (2011, p. 55), was to catalyse higher levels of employment by people with disability, currently well below OECD average. To achieve this goal, the NDIS will fund the assistive technology devices and equipment needed by some people to gain and sustain work, services assisting in building skills and capacity to participate in employment, and personal assistance with transport to and from the workplace (NDIS, n.d.).

Pre-publication 'accepted' version

For full publication visit: https://www-tandfonlinecom.ezp.lib.unimelb.edu.au/doi/abs/10.1080/08111146.2018.1481026 
The NDIS will also create labour opportunities in the disability services sector as well as enabling family carers-the majority of whom are women-to return to the workforce by reducing their caring responsibilities. Modelling undertaken by National Disability Services and Every Australian Counts (2016) estimated that in NSW alone, the NDIS will create 37 400-46 400 new jobs, for between 7800 and 12,400 people with disability, 10,700 relatives relieved from primary care duties and 25,000 new disability support workers. A similar impact was projected for Victoria. Little is known, however, about the specific industries and occupations in which NDIS participants and their family carers are likely to participate, their terms of employment, housing and transport implications of their entry into the labour market and the impact on other workers or work-seekers in these industries.

The National Disability Insurance Agency (NDIA) itself has become a relatively large employer of people with disability, with approximately $16 \%$ of the agency's staff identifying as having a disability (NDIS, 2015). However, almost all of these are people with physical and sensory disability, highlighting differentiated outcomes for people with different disabilities. If even the NDIA does not employ people with cognitive disability, other businesses are even less likely to do so.

For existing disability support workers, the NDIS is likely to bring significant changes in the conditions of employment. In 2010, the disability services workforce was estimated at approximately 68,700 workers. Although increasingly professionalised $-76 \%$ are qualified with at least a Certificate III-the disability support workforce is mired by issues such as low skill levels, lack of career paths, low wages and increasing casualization. The shift towards individualised funding is expected to bring even greater casualisation of frontline staff (Green and Mears, 2014).

\section{Mainstream services}

Access to mainstream services has been an enduring policy aim since the 1970s, and is central to social inclusion and the quality of life of people with disability (Bigby and Fyffe, 2012). While people with disability can access mainstream systems such as education, health and public transport, the services offered are often not responsive to their needs. As a result they continue to experience high levels of segregation in specialist services, or quasi separate systems, such as special schools.

Pre-publication 'accepted' version

For full publication visit: https://www-tandfonlinecom.ezp.lib.unimelb.edu.au/doi/abs/10.1080/08111146.2018.1481026 
Inclusion in mainstream services is also a central goal of the NDIS and the complementary National Disability Strategy (COAG, 2011). Funds from individualised NDIS packages will be used to purchase certain specialist disability services, but "wherever possible" (NDIS, n.d.) will assist participants to access mainstream systems. Through the ILC the NDIS will fund Local Area Coordinators whose role will be to link people with disability to mainstream systems. The ILC will also provide resources to assist mainstream services to include people with disability, and assistance for participants to build their capacity to use mainstream services (NDIS, n.d.).

For example, the NDIS will fund supports that enable participants to attend mainstream schools, including assistance with self-care at school, specialist transport to school, equipment (eg communication aids) or intensive support to transition between schools. However, schools will be required to make "reasonable adjustments" (NDIS, n.d.) to their curriculum and physical infrastructure to be more inclusive of students with a disability. It will be the onus of the mainstream education system to provide learning assistants and learning-specific aids and equipment. In 2011, the majority of children with a disability (65.9\%) already attended regular classes in mainstream schools, giving rise to concerns about inadequate resources, skills and training for teachers to effectively support inclusion of students with a disability, with potentially detrimental academic outcomes for students with and without a disability (Round et al., 2016).

Similar challenges are expected with respect to NDIS participants' access to mainstream health services, from local General Practitioners (GPs), through to highly specialist medical services and hospitals accessed from wide regional catchments. People with disability, particularly intellectual disability, experience communication difficulties with health professionals that affect the quality of the health care they receive. These difficulties are underpinned by limited skills and negative attitudes held by health professionals, including limited views of their roles and responsibilities as health care providers for people with intellectual disability (Krahn et al., 2006). Poor healthcare practices include for example over-prescription of antipsychotic drugs to people with intellectual disability who have no record of severe mental illness, associated with high morbidity (Trollor and Salomon, 2016). To assist use of mainstream health services by people with disability, the NDIS will fund allied health and other therapy - including physiotherapy, speech therapy or occupational therapy - where this is required as a result of the participant's impairment. An NDIS Local

Pre-publication 'accepted' version

For full publication visit: https://www-tandfonlinecom.ezp.lib.unimelb.edu.au/doi/abs/10.1080/08111146.2018.1481026 
Area Coordinator may also assist a person to connect and negotiate with a mainstream healthcare provider. However, the mainstream health system will still be responsible for all clinical and medical treatment, and to make appropriate adjustments where necessary to be more inclusive of patients with a disability (NDIS, n.d.).

As French (2012, p. 54) argued, the reasonable adjustment required from mainstream services is "a feature of the formal equality paradigm that is incapable of securing genuine equality" for people with disability. In the past, the required adjustments from mainstream services, such as schools, have not been provided, and students with intellectual disability, for example, often experienced exclusion from education and bullying in schools. The impact of antidiscrimination legislation in requiring reasonable adjustments has been minimal:

In fact, it is difficult to identify any leading case, indeed any case, where the DDA (Disability Discrimination Act) has resulted in substantial positive change for an individual with intellectual disability, still less for persons with intellectual disability as a class. (French, 2012, p. 54).

For French (2012), the paradigm of formal equality-in which Australian antidiscrimination legislation currently operates-fails because it disregards rather than recognises and embraces difference. To make mainstream services more inclusive of people with disability, their disability must be recognised and significant positive rather than formal equality measures are needed. The Disability Discrimination Act (1992) triggered only few legal actions by individuals with disability, and only a single anti-discrimination class action that resulted in more substantial achievements for people with intellectual disabilities, the 2016 settlement of a class action by 10,000 workers with intellectual disability against the Australian Disability Enterprises (Clegg and Bigby, 2017).

\section{Urban management and governance}

The NDIS full rollout will see oversight of all disability services funding transferred from most states and territories ${ }^{2}$ to a national body - the NDIA. State governments are also expected to withdraw from direct provision of disability services, which will be delivered by not-for-profit and private services.

These changes initiated by the NDIS will have significant implications for urban governance and management. The withdrawal from both funding and delivery of disability services will require some reorganisation of state governments, which in Australia - more so than other

Pre-publication 'accepted' version

For full publication visit: https://www-tandfonlinecom.ezp.lib.unimelb.edu.au/doi/abs/10.1080/08111146.2018.1481026 
federal democracies - directly and indirectly govern and manage metropolitan regions and the provision of urban services such as transport, human services, hydraulic services, housing, education and others.

Funding and provision of disability services currently represents a substantial activity in the portfolio of state governments. In NSW, disability services represented $50 \%$ of the Department of Family and Community Services total 2015-16 budget (NSW Government, 2015, p. 17). In Victoria, disability services accounted for approximately $9 \%$ of the total output cost of the Department of Human Services in Victoria, second only to health services and nearly a third of the total output when health services are excluded (Victorian Government, 2016, p. 217).

The gap left by state governments in delivery of services will be filled by non-governmental organisations (NGOs) and for-profit service providers. These changes are also likely to affect municipalities, which also function as important human service providers and managers in Australia's uniquely distributed urban governance systems. The transition will include transfer of disability services staff and potentially also assets from state governments to nongovernment service providers. The growing role of the not-for-profit sector will lead to an overall diversification of urban governance structures in the disability sector and beyond, involving a plethora of organisations with varied composition of councils or boards and different approaches to service user participation in governance (Green and Mears 2014). At the same time, diversity in the NGO disability services sector could diminish if, in anticipation of the NDIS, smaller organisations amalgamate into larger, franchised agencies operating across multiple locations within and across states. This could potentially have implications for the ability of NGOs to draw on localised social capital to support people with disability.

Although state governments are likely to retain certain responsibilities in relation to the regulation and governance of disability services, the withdrawal from funding and delivery of disability services represents a substantial restructuring of state government operations. This will have potential flow on effects on other state government departments, as well as the NGO sector and municipal governments. It will further compound a long run privatisation of urban collective consumption in Australia, potentially deepening the challenges of coordination and governance already to the fore in the major cities (Gleeson, 2017).

Pre-publication 'accepted' version

For full publication visit: https://www-tandfonlinecom.ezp.lib.unimelb.edu.au/doi/abs/10.1080/08111146.2018.1481026 


\section{Cultural diversity}

People with disability-especially those with intellectual disability-experience relatively high levels of social exclusion in terms of participation in their communities' social networks and civic and cultural life. Deinstitutionalisation and community care reduced levels of segregated living and enabled greater physical community presence. However, these policies have been less effective in facilitating more meaningful participation of people with disabilities in the form of convivial encounters or lasting relationships with other members of the community beyond their distinct social space of family, support staff and co-residents in group homes (Clement and Bigby, 2009; Verdonschot et al., 2009; Wiesel and Bigby, 2014). Barriers to community participation by people with disability are manifold and complex. These range from barriers within the disability services system (eg staff practices limiting opportunities for encounter and participation) to wider societal barriers underpinned by exclusionary community attitudes, practices and spaces (Clement and Bigby, 2009; Wiesel and Bigby, 2014).

Enhancing community participation and inclusion of people with disability is a primary objective of the NDIS, seen as essential to improvement in health, employment, education, income and quality of life outcomes for people with disability, while reducing the long term costs of support funded by the NDIS (NDIS, n.d.). The NDIS will fund certain types of personal supports, such as transport or communication aids, to assist people with disability to participate in social and cultural activities. In addition, the NDIS will also fund more general programs aiming to change community attitudes through the ILC component of the scheme (NDIS, 2016).

Increased participation of people with disability can be understood as adding new layers to the multicultural richness of Australian cities. As a settler society with about a quarter of Australia's population born overseas, and about a fifth speaking a language other than English at home (ABS, 2013), cultural diversity has often been understood in Australia in relation to its ethnic diversity. Disability is often neglected as a form of social and cultural difference in debates about multiculturalism (Jakubowicz and Meekosha, 2003).

The disability rights movement's campaigns for deinstitutionalisation and equal economic and social rights also expressed a desire for recognition as a cultural group that plays "a positive and creative role in increasing the wider societal understanding of the human condition" (Jakubowicz and Meekosha 2003, p. 189), as opposed to isolated individuals

Pre-publication 'accepted' version

For full publication visit: https://www-tandfonlinecom.ezp.lib.unimelb.edu.au/doi/abs/10.1080/08111146.2018.1481026 
defined by medically diagnosed difference and needs. As noted by Jakubowicz and Meekoasha (2003), major contributions to literature, film, drama, sport, music and other cultural expressions produced by and about people with disability, are but a few of the significant contributions this group makes to cultural diversity in Australia and elsewhere. This has at least three implications for an urban agenda. First, there is the question of universal access to creative and playful public space, not only parks and playgrounds, but streets and squares (Dee, 2015). Second, there is a question of participatory local governance and the inclusion of people with disability, not only in co-evaluation of specific programs, or as members of advisory boards but also more general inclusion in a new era of citizens juries and e-democracy (Frawley and Bigby, 2011; Robinson et al., 2014; Aulich and Artist, 2015). Third, there is the question of the role of the arts and other creative activities in mediating inclusion (Grant, 2014).

\section{New urban geographies}

The outcomes of the NDIS will be determined not only by the design and implementation of the Scheme itself, but also by the opportunities and barriers presented by urban labour and housing markets, suburban communities and mainstream social, health and education services.

The current urban condition in Australia is far from ideal for the implementation of such an ambitious scheme. Publicly funded mainstream education, health and social housing providers struggle to meet existing levels of demand, let alone the growth in demand expected to be triggered by the NDIS. While the NDIS will create new jobs for disability support workers, it will also increase the precarity of labour in the sector for both existing and new staff. There is a concern that the restructuring of state governments will leave human services departments weakened in their capacity to regulate and lead both disability and other social services.

Notwithstanding these critical issues, the NDIS does have the potential to change Australian cities, and ultimately for the better. People with disabilities' lives will be enriched by higher levels of support to participate in the community, while contributing to the social, cultural and economic thriving of multicultural Australian cities. For the NDIS to fulfil this potential, there is a need for a paradigm shift in mainstream urban policy, services delivery and legislation, from a formal to a positive equality approach. The NDIS approach to service

Pre-publication 'accepted' version

For full publication visit: https://www-tandfonlinecom.ezp.lib.unimelb.edu.au/doi/abs/10.1080/08111146.2018.1481026 
users' rights, choice and control will need to filter into other social services domains that are still dominated by a more paternalistic welfare approach. Such changes will benefit not only people with disability but other disadvantaged minority groups. Indeed, the NDIS offers an instrumental case study for the study of individualised welfare as an emerging social policy paradigm in the neo-liberal city (Jacobs et al., 2016).

It is time for Australian urban research to engage more directly with the NDIS, as part of the broader interest in the social justice in cities, social inclusion and exclusion in cities. It is important that studies of mainstream labour markets, housing, health, education and other urban services pay more attention to people with disability, who represent approximately a fifth of the Australian population.

It is essential that new research on the impact of the NDIS on cities remains sensitive to socially and spatially differentiated outcomes. As the NDIS rolls out nationally, highly variable outcomes are likely to gradually become evident in different cities or sub-regions and across different urban and non-urban domains. Understanding this spatial variability will be key to understanding the national impact of the NDIS.

In assessing these spatially differentiated outcomes, the diversity of people with disability as a population must also be recognised, including the fluid ways in which disability intersects with multiple other social categories such as gender, age, class and ethnicity (Bê, 2012). New forms of intersectionality and segmentation can be expected to emerge with the NDIS. This will include, for example, differences between those who are eligible for individualised NDIS funding packages and those who are not; between the even smaller group who will get funding for specialist disability accommodation and those who will not; and, between people with physical, sensory, psychosocial and cognitive disability whose voices are unevenly represented both within and beyond the disability services sector. Given its power to reshape social geographies, the NDIS is in fact a city (and regional) policy that bears serious, preemptive consideration in Australian urban scholarship.

\section{End notes}

\footnotetext{
${ }^{1}$ Neilson Associates (1990, p. 8) estimated approximately 9,000 people with intellectual disability lived in institutions in 1988 .
}

Pre-publication 'accepted' version

For full publication visit: https://www-tandfonlinecom.ezp.lib.unimelb.edu.au/doi/abs/10.1080/08111146.2018.1481026 
${ }^{2}$ Possibly with the exception of Western Australia that has announced negotiations with the Commonwealth Government on a 'nationally consistent but state-run National Disability Insurance Scheme' (WA Government, 2016).

\section{References}

Australian Bureau of Statistics (ABS), 2013. Australian, social trends, April 2013, http://www.abs.gov.au/AUSSTATS/abs@.nsf/Lookup/4102.0Main+Features30April+2013 Australian Bureau of Statistics (ABS), 2016. Regional Population Growth, Australia, 201415, http://www.abs.gov.au/ausstats/abs@.nsf/mf/3218.0 Anglicare 2015, Rental Affordability Snapshot, April, 2015. Canberra: Anglicare Australia. Aulich, C. and Artist, S., 2015. 'Emerging from the chrysalis: participatory governance in Australian local government', Asian review of public administration, 22 (1), 48-63.

Australian Human Rights Commission (AHRC), n.d. Face the facts: Cultural diversity, https://www.humanrights.gov.au/face-facts-cultural-diversity

Austraian Institute of Health and Welfare (AIHW), 2017. Housing Assistance in Australia, 2017. https://www.aihw.gov.au/reports/housing-assistance/housing-assistance-in-australia2017/contents/social-housing-tenants

Baldry, E., Dowse, L., and Clarence, M., 2012. People with mental and cognitive disabilities: pathways into prison.

https://www.mhdcd.unsw.edu.au/sites/www.mhdcd.unsw.edu.au/files/u18/pdf/MHDCDbackgr oundOutlaws\%20Conf1.pdf

Baum, S. and Gleeson, B., 2010. 'Space and place: social exclusion in Australia's suburban heartlands', Urban Policy and Research, 28 (2), 135-159.

Bê, A., 2012. 'Feminism and disability: A cartography of multiplicity', Routledge handbook of disability studies. Routledge, London, pp. 363-375.

Bigby, C. and Fyffe, C., 2012. 'Responsiveness of mainstream services to people with intellectual disability: Challenges for the National Disability Insurance Scheme', in Bigby C, Fyffe C, (eds.) Making mainstream services accessible and responsive to people with intellectual disability: what is the equivalent of lifts and Labradors? Proceedings of the Seventh Annual Roundtable on Intellectual Disability Policy, 6 December 2012, http://hdl.handle.net/1959.9/494836

Pre-publication 'accepted' version For full publication visit: https://www-tandfonlinecom.ezp.lib.unimelb.edu.au/doi/abs/10.1080/08111146.2018.1481026 
Bonyhady, B., 2016. Reducing the inequality of luck: Keynote address at the 2015 Australasian Society for Intellectual Disability National Conference, Research and Practice in Intellectual and Developmental Disabilities, 3 (2), 115-123.

Chamberlain, C. and MacKenzie, D., 2014. 'Definition and counting: where to now?' Homelessness in Australia: An Introduction. Sydney: NewSouth Publishing.

Clegg, J., and Bigby, C., 2017. 'Debates about dedifferentiation: twenty-first century thinking about people with intellectual disabilities as distinct members of the disability group', Research and Practice in Intellectual and Developmental Disabilities, 4(1), 80-97. Clement, T. and Bigby, C., 2009. 'Breaking out of a distinct social space: Reflections on supporting community participation for people with severe and profound intellectual disability', Journal of Applied Research in Intellectual Disabilities, 22 (3), 264-275. Council of Australian Governments (COAG), 2011. National Disability Strategy, https://www.dss.gov.au/sites/default/files/documents/05_2012/national_disability_strategy_2 010_2020.pdf

Dear, M.J. and Wolch, J.R., 1987. Landscapes of Despair: From Deinstitutionalization to Homelessness. New Jersey: Princeton University Press.

Dee, M., 2015. 'Young people and urban public space in Australia-creating pathways to community, belonging and inclusion', International Journal of Social Science Research, 3 (2), 138-151.

Disability Housing Futures, 2016. Disability Housing Futures Working Group Final Report. http://udiavic.com.au/UDIA/media/UDIAPDFS/One-off\%20files/DHF-Report-April-2017.pdf Disability Housing Futures, 2017. People with disability living in inadequate housing: prevalence, trends, and health and workforce participation outcomes.

http://nahc.org.au/documents/DHF_Report_April_2017.pdf

Frawley, P. and Bigby, C., 2011. Inclusion in political and public life: The experiences of people with intellectual disability on government disability advisory bodies in Australia, Journal of Intellectual and Developmental Disability, 36 (1), 27-38.

French, P., 2012. 'The concept of reasonable adjustment in Commonwealth disability discrimination law and its implications for equality for persons with intellectual disability', in Bigby, C., and Fyffe, C. (eds.) Making mainstream services accessible and responsive to people with intellectual disability: what is the equivalent of lifts and Labradors? Proceedings

Pre-publication 'accepted' version

For full publication visit: https://www-tandfonlinecom.ezp.lib.unimelb.edu.au/doi/abs/10.1080/08111146.2018.1481026 
of the Seventh Annual Roundtable on Intellectual Disability Policy, 6 December 2012, http://hdl.handle.net/1959.9/494836

Dalton, T., \& Ong, R. (2007). Welfare to Work in Australia: Disability Income Support, Housing Affordability and Employment Incentives. International Journal of Housing Policy, 7(3), 275-297.

Gleeson, B., 1999. Geographies of disability. London: Routledge.

Gleeson, B. 2017 'The metropolitan condition' in Hamnett, S. \& Freestone, R., (eds) Planning Metropolitan Australia. Routledge, Abingdon, UK, 170-186

Goggin, G. and Wadiwel, D., 2014. Australian disability reform and political participation.

http://www.australianreview.net/digest/2014/09/goggin_wadiwel.html

Grant, C., 2014. 'Participating in arts-and cultural-sector governance in Australia:

Experiences and views of people with disability', Arts \& Health 6 (1), 75-89.

Green, J. and Mears, J., 2014. 'The Implementation of the NDIS: Who Wins, Who Loses?'

Cosmopolitan Civil Societies, 6 (2), 25-39.

Hayward, D., 1996. 'The reluctant landlords? A history of public housing in Australia', Urban policy and research, 14 (1), 5-35.

Infrastructure Victoria, 2016. Victoria's 30 years infrastructure strategy. Melbourne:

Victorian Government

Jacobs, K., Hulse, K., Stone, W. and Wiesel, I., 2016. Individualised housing assistance:

findings and policy options, AHURI Final Report, 269.

Jakubowicz, A. and Meekosha, H., 2003. 'Can multiculturalism encompass disability', in:

Riddell S, Watson N (eds) Disability, culture and identity, pp. 180-199.

Jones, M., 1972. Housing and poverty in Australia, Melbourne University Press, Melbourne.

Krahn, G.L., Hammond, L., and Turner, A., 2006. A cascade of disparities: health and health care access for people with intellectual disabilities, Mental retardation and developmental disabilities research reviews, 12 (1), 70-82.

Major Cities Unit, Department of Infrastructure and Development, Australian Government, 2015. State of Australian Cities 2014-2015: progress in Australian region https://infrastructure.gov.au/infrastructure/pab/soac/files/2015_SoAC_full_report.pdf Mansell, J., and Beadle-Brown, J., 2009. Dispersed or clustered housing for adults with intellectual disability: A systematic review. Journal of Intellectual \& Developmental Disability, 34(4), 313-323.

Pre-publication 'accepted' version For full publication visit: https://www-tandfonlinecom.ezp.lib.unimelb.edu.au/doi/abs/10.1080/08111146.2018.1481026 
Mental Health Council of Australia (MHCA), 2009. Home Truths: Mental health, housing and homelessness in Australia,

https://mhaustralia.org/sites/default/files/imported/component/rsfiles/publications/MHCA_H ome_Truths_Layout_FINAL.pdf

Mental Health Services in Australia, n.d. Specialised mental health bed and patient days. https://mhsa.aihw.gov.au/resources/facilities/beds/

National Capital Authority (NCA), 1996. 'Institutional reform', Better Cities Occasional Paper Series, 2(5).

National Disability Insurance Scheme (NDIS), 2015. National Disability Insurance Agency, Annual Report 2014-15, https://www.ndis.gov.au/html/sites/default/files/documents/AnnualReport/2014-15-Annual-Report1.pdf

National Disability Insurance Scheme (NDIS), 2016. Information, Linkages and Capacity

Building Commissioning Framework,

https://www.ndis.gov.au/medias/documents/hf4/ha1/8799111970846/ILC-CommissioningFramework-PDF-3MB-.pdf

National Disability Insurance Scheme (NDIS), 2018. About the NDIS, https://www.ndis.gov.au/about-us/what-ndis

National Disability Services (NDS) and Every Australian Counts (EAC), 2016. Economic Benefits of the NDIS in NSW. Accessed $29^{\text {th }}$ May 2017, http://www.everyaustraliancounts.com.au/wp-content/uploads/NDIS-Economic-BenefitsNSW.pdf

National Housing Supply Council (NHSC), 2013. Housing supply and affordability issues 2012-13. Canberra: National Housing Supply Council.

National Insurance Disability Scheme (NDIS), n.d. Connecting with the mainstream, https://www.ndis.gov.au/people-disability/connecting-mainstream

Neilson Associates, 1990. The Housing Impacts of Deinstitutionalisation Policies, Australian Housing Research Council, Canberra.

NSW Government, 2015. 'Empowering people to live fulfilling lives and achieve their potential'. https://www.facs.nsw.gov.au/_data/assets/pdf_file/0020/318305/FACS_budgetsummary_2015-16.pdf

OECD, 2016. How does Australia compare? Employment outlook 2016. https://www.oecd.org/australia/Employment-Outlook-Australia-EN.pdf

Pre-publication 'accepted' version For full publication visit: https://www-tandfonlinecom.ezp.lib.unimelb.edu.au/doi/abs/10.1080/08111146.2018.1481026 
Productivity Commission, 2011. Disability Care and Support. Canberra: Productivity Commission.

Randolph, B. and Tice, A., 2016. Relocating Disadvantage in Five Australian Cities: Sociospatial Polarisation under Neo-liberalism, Urban Policy and Research (Online before print), $1-19$.

Robinson, S., Fisher, K.R., and Strike, R., 2014. 'Participatory and inclusive approaches to disability program evaluation', Australian Social Work, 67 (4), 495-508.

Round, P.N., Subban, P.K., and Sharma, U., 2016. '"I don't have time to be this busy." Exploring the concerns of secondary school teachers towards inclusive education', International Journal of Inclusive Education, 20 (2), 185-198.

Searle, G., \& Bunker, R. (2010). Metropolitan strategic planning: an Australian paradigm? Planning Theory, 9(3), 163-180.

Stimson, R.J., 2011. 'Australia's changing economic geography revisited', Australasian Journal of Regional Studies, 17 (1), 22-45.

Stone, W., Sharam, A., Wiesel, I., Ralston, L., Markkanen, S., and James, A., 2015. 'Accessing and sustaining private rental tenancies: critical life events, housing shocks and insurances', AHURI Final Report 259.

Trollor J., Salomon C., 2016. Unnecessary psychotropic drug prescription in primary care for people with intellectual disability, Evidence-Based Mental Health ,19, 62.

Troy, L. (2017) Red herrings in urban renewal: Compact city planning and infrastructure efficiencies, paper presented at the Australasian Housing Researchers Conference, 15 February 2017, Melbourne.

Verdonschot, M.M., De Witte, L.P., Reichrath, E., Buntinx, W.H.E., and Curfs, L.M., 2009. 'Community participation of people with an intellectual disability: a review of empirical findings', Journal of Intellectual Disability Research, 53 (4), 303-318. Victorian Government, 2016. Getting it done: Victorian Budget 16/17, Service Delivery Budget Paper No. 3. http://budgetfiles201617.budget.vic.gov.au/2016-17+State+Budget++ BP3+Service+Delivery.pdf

Western Australia Government, 2016. Governments agree on state-run NDIS, https://news.wa.gov.au/joint-media-statement-governments-agree-the-way-forward-for-ndisin-wa/?utm_source=DSC+Contacts\&utm_campaign=837d71b780- 
WA_NDIS_2016_12_02\&utm_medium=email\&utm_term=0_153f43591e-837d71b78015598031

Whiteford, P., 2013. Australia: inequality and prosperity and their impacts in a radical welfare state. Canberra: Australian National University.

Whiteford, H.A. and Buckingham, W.J., 2005. 'Ten years of mental health service reform in Australia: are we getting it right?’ The medical Journal of Australia, 182 (8), 396-400.

Whitzman, C. and Slater, T., 2006. 'Ghetto Village Land: Myth and Housing Policy in Parkdale Toronto, 1883-2003', Urban Affairs Review, 41 (5), 673-696.

Wiesel, I. and Bigby, C., 2014. Being recognised and becoming known: encounters between people with and without intellectual disability in the public realm. Environment and Planning A, 46 (7), 1754-1769.

Wiesel, I. and Bigby, C., 2015. 'Movement on shifting sands: Deinstitutionalisation and people with intellectual disability in Australia, 1974-2014', Urban Policy and Research, 33 (2), pp. 178-194.

Wiesel, I., Laragy, C., Gendera, S., Fisher, K.R., Jenkinson, S., Hill, T., Shaw, W. and Bridge, C., 2015. 'Moving to my home: housing aspirations, transitions and outcomes of people with disability', AHURI Final Report 246.

Wiesel, I., Fisher, K.R., Cornell, V., 2017. How will the new Specialist Disability Accommodation rules impact choice and control? Around the House, 109, pp. 35-37.

Yates, J., 2011. 'Explaining Australia's trends in home ownership', Housing Finance International (Winter), pp. 6-13.

Pre-publication 'accepted' version

For full publication visit: https://www-tandfonlinecom.ezp.lib.unimelb.edu.au/doi/abs/10.1080/08111146.2018.1481026 